\title{
AGE AND CORRELATION OF SUPRACRUSTAL ROCKS IN THE FREDERIKSHÅBS ISBLINK AREA
}

\author{
Peter R. Dawes
}

\section{Introduction}

Eight weeks field work was spent in the Frederikshåbs Isblink area as a continuation to the investigations carried out in 1967. Half the time was used to further the work on Dalagers Nunatakker and half was spent on the gneisses and supracrustal rocks north of the Isblink in an attempt at correlation across the Isblink between the gneiss-amphibolite complex of the Frederikshåb area (see Jensen, 1966) and the Ravns Stor $\phi$ region (Windley et al., 1966; Windley, 1968).

\section{Work on Dalagers Nunatakker}

An important addition to the 1967 work was the examination on the northern nunatak of a succession of metavolcanic rocks, composed of pillow lavas, pyroclastics, hornblende schists, metagabbro layers and ultrabasic rocks. These rocks overlie granite and granodioritic gneiss. No visible discordance occurs between them. The unmigmatised metavolcanics pass downwards into a transition zone where metavolcanic rocks are veined by garnet-bearing granite and pegmatite sheets. This zone grades into a zone where metavolcanic schlieren exist within granite and granitic gneiss. The metavolcanic rocks and the underlying gneisses and granite have amphibolite facies mineralogy. The metavolcanics have not been severely deformed and flattened pillow structure in the lava, and compositional banding and magmatic layering in the metagabbro, are well perserved. Folds in the succession are rare.

Work north of the Isblink

North of the Isblink, $25 \mathrm{~km}$ to the north-west of Dalagers Nunatakker, a further metavolcanic succession occurs. Windley has already described the nature of this Ravns Stor $\phi$ supracrustal belt and its relationship to the underlying gneisses (Windley, 1968; Windley et al.1966). By helicopter the author was able to visit the north-eastern part of the belt, an area inaccessible to Windley, and thus some additional points are worth making here. 
The metavolcanics in the north-eastern part of the belt are in amphibolite facies corresponding to the grade of the surrounding gneisses. There is thus an increase in metamorphic grade along the strike of the belt from the south-west where, according to Windley (1968), the rocks are in greenschist facies. The metavolcanic rocks are amphibolitic schists in the north-east and little evidence for their metavolcanic nature remains. The belt also decreases in width and the schists become migmatised and intercalated with the gneisses. In the extreme north-east the belt closes around a tight NE-trending fold and the strike turns towards the west and not towards the east and south-east as previously considered.

\section{Correlation and age}

It is suggested that the metavolcanic rocks of the Ravns Stor $\phi$ area and those on the northern nunatak of Dalagers group are the same age. Both have similar characteristics and have identical relationships to the gneisses. Whether other amphibolitic material in the Precambrian basement of the Frederikshåb area has the same age is difficult to decide but the fact that the typical amphibolite layers in the gneiss complex have been strongly folded and migmatised at least five times (see Andrews, 1968) suggests to the present author that the metavolcanic rocks on the northern nunatak and in the Ravns Stor $\phi$ area, which are only slightly deformed, are younger in age and post-date an earlier gneissic basement. This is supported by the fact that metamorphosed basic dykes are common in the gneisses on Dalagers Nunatakker (Dawes, 1968), and also were found this summer in the gneisses north of the Isblink, and yet they are absent in the supracrustal rocks. These basic dykes cut some amphibolitic layers and inclusions in the gneisses, amphibolitic material which is complexly folded and migmatised, and it is suggested that such layers and inclusions are older than the supracrustal metavolcanic rocks. Reworking on th, basement, resulting in the incorporation of the younger basic material into the gneisses, makes the recognition of two ages of amphibolitic material extremely difficult, especially where basic dykes are lacking. It is considered most likely that the hornblende schists on Jensens Nunatakker, first noted by Kornerup (1879) and commented on by Jensen (1968), are the same age as the Ravns Stor $\phi$ metavolcanics and thus part of the cover. 


\section{References}

Andrews, J.R. (1968) The structural chronology in the Nigerdlikasik area, Frederikshåb district. Rapp. Grфnlands geol. Unders., Nr. 15, 45-48.

Dawes, P.R. (1968) Geological investigations on Dalagers Nunatakker, with special reference to metamorphosed basic dykes. Rapp. Grфnlands geol. Unders., Nr. 15, 35-40.

Jensen, S. B. (1966) Field work in the Frederikshåb area. Rapp. Grønlands geol. Unders., Nr. 11, 32-35.

Jensen, S. B. (1968) Field work in the Frederikshåb area. Rapp. Grфnlands geol. Unders., Nr. 15, 40-44.

Kornerup, A. (1879) Geologiske Iagttagelser fra Vestkysten af Gronland $\left(62^{\circ} 15^{\prime}-64^{\circ} 15^{\prime}\right.$ N. B. $)$. Meddr Grønland, Bd. 1, 77-139.

Windley, B.F. (1968) New field relations from the early Precambrian of West Greenland. Rapp. Grфnlands geol. Unders., Nr. 15, 27-31.

Windley, B. F., Henriksen, H., Higgins, A. K., Bondesen, E. and Jensen, S. B. (1966) Some border relations between supracrustal and infracrustal rocks in South-West Greenland. Rapp. Grфnlands geol. Unders. , Nr. 9.

FIELD WORK IN THE FREDERIKSHÅB DISTRICT

Stig Bak Jensen

In 1968 the field work in the Frederikshåb area was carried out by 14 geologists each helped by an assistant. 10 geologists were involved in the geological mapping, each mapping his own area; one geologist made a detailed study and collected specimens of ultrabasic rocks from gneisses and amphibolitic horizons; one geologist investigated Ketilidian supracrustal rocks east of Ivigtut and two geologists worked in Quaternary geology south of Frederikshåb Isblink. 